\title{
POLA PENCARIAN INFORMASI DI INTERNET
}

Oleh: Rahmi Rivalina *)

\section{Abstrak}

Penelitian ini bertujuan untuk mengetahui pola pencarian informasi mahasiswa ketika menelusur di Internet. Acuan yang digunakan dalam penelitian adalah model pencarian informasi di lingkungan elektronik yang dikemukakan oleh Marchionini. Penelitian dilakukan dengan menggunakan metode survai dengan pendekatan analisis kuantitatif. Pengumpulan data dilakukan dengan menggunakan teknik kuesioner, dengan pengolahan data secara deskriptif. Populasi penelitian adalah mahasiswa pascasarjana program magister angkatan 2001 yang sedang menyusun tesis dan menggunakan internet sebagai sumber informasi. Responden terdiri dari 331 mahasiswa yang berasal dari 12 fakultas dan program pascasarjana. Hipotesis yang diuji dalam penelitian ini adalah hubungan antara frekuensi menelusur dengan pengetahuan mengenai cara menelusur. Pengujian hipotesis dilakukan dengan menggunakan uji statistik Chi-Square. Hasil pengujian hipotesis menunjukkan bahwa tidak ada hubungan antara frekuensi menelusur dengan pengetahuan mengenai cara menelusur mahasiswa. Hasil analisis menunjukkan bahwa pola pencarian informasi mahasiswa yang diamati dalam penelitian ini tidak sesuai dengan model pencarian informasi Marchionini. Dalam melakukan pencarian informasi mahasiswa cenderung menggunakan teknik browsing dan berdasarkan karakteristiknya mahasiswa dapat dikelompokkan sebagai pengguna pemula.

\section{PENDAHULUAN}

*) Dra. Rahmi Rivalina, M.Hum., adalah Koordinator Perpustakaan Teknologi Komunikasi dan Informasi Pendidikan, Depdiknas. 


\section{A. Latar Belakang}

Penjajagan awal penulis di kampus UI Depok pada tanggal 26-30 April 2002 menemukan bahwa pusat layanan Internet mahasiswa, $M W e b$, ketika pertama kali dibuka pada tahun 2000, pengunjung pernah mencapai 900 orang/hari. Pada tahun 2001 M.Web dikembangkan menjadi 5 tempat. Disamping $M W e b$, Unit Pelaksana Teknis (UPT) perpustakaan dan perpustakaan fakultas juga menyediakan fasilitas Internet untuk mahasiswa.

Hal ini menunjukkan ada kebutuhan mahasiswa untuk berinteraksi dengan teknologi dalam rangka memutakhirkan pengetahuan, mengerjakan tugas, mempersiapkan penyusunan karya ilmiah baik skripsi maupun tesis. Pada waktu penyusunan karya ilmiah mahasiswa berada dalam situasi problematis. Situasi ini dipertegas dengan pendapat seorang guru besar IPB, Khomsan (2002), bahwa mahasiswa yang sedang dalam tahap pembimbingan seringkali menghilang dengan berbagai alasan, ada yang pusing karena rumusan.

Untuk menjembatani kebutuhan informasi tersebut biasanya mahasiswa berkunjung ke pusat informasi perpustakaan. Perpustakaan seringkali tidak dapat memenuhi kebutuhan pengguna yang luas dan beragam. Perpustakaan mempunyai keterbatasan koleksi baik buku, jurnal dan karya ilmiah lainnya.

Sehubungan dengan fenomena tersebut maka Internet merupakan salah satu solusi untuk mendapatkan informasi. Pencarian informasi di Internet membutuhkan keterampilan menelusur dan pemahaman teknologi.

\section{B. Perumusan Masalah}

Bila seseorang merasakan pengetahuan yang dimilikinya tentang sesuatu bagian dari kegiatan 'kurang' atau 'tidak cukup'disebut dengan kesenjangan informasi. Kesenjangan ini merupakan dasar kebutuhan informasi, dan awal dari proses pencarian informasi. Pertanyaan penelitian ditetapkan sebagai berikut: 
a . Bagaimana pola pencarian informasi mahasiswa pascasarjana UI ketika mencari informasi di Internet?

b. Apakah ada hubungan antara frekuensi menelusur dengan pengetahuan menelusur mahasiswa pascasarjana UI ketika mencari informasi di Internet?

\section{Batasan Penelitian}

a. Mahasiswa pascasarjana program magister angkatan 2001, Universitas Indonesia yang sedang menyusun tesis dan menggunakan media elektronik, Internet sebagai sumber informasi.

b. Menggunakan model pencarian informasi Marchionini untuk tahap yang seharusnya.

\section{TINJAUAN PUSTAKA}

\section{A. Model Pencarian Informasi}

Model pencarian informasi merupakan tahap-tahap pencarian informasi yang ditandai ciri-ciri tetentu dari masing-masing tahap. Sebagian besar model pencarian informasi bebentuk putaran yang diprakarsai oleh kebutuhan informasi pencari informasi (Borgman, 2000:109).

Model Marchionini menggambarkan proses pencarian informasi di lingkungan elektronik dalam bentuk algoritma dengan 9 unsur, tetapi dalam 8 tahapan yaitu: 1). recognize (mengenali masalah informasi) 2). accept (menerima masalah informasi) 3). define problem (mendefinisikan dan memahami masalah) 4). select source (memilih sebuah sistem penelusuran) 5). formulate query (merumuskan sebuah pertanyaan) 6). execute query (melaksanakan penelusuran) 7). examine result (memeriksa hasil penelusuran) 8). extract info (memilah informasi) dan 9) reflect/stop, (mengakhiri penelusuran), seperti yang terlihat pada gambar 1 : 


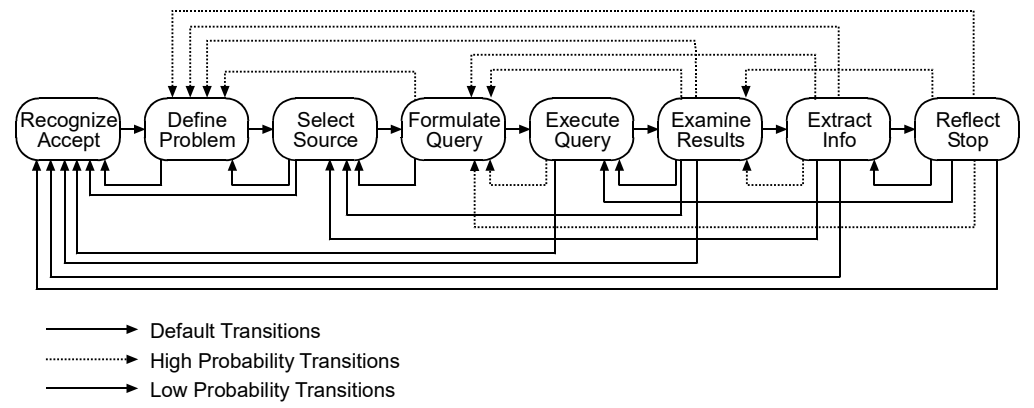

Gambar 1.

Model Pencarian Informasi Marchionini

Model ini dilengkapi dengan 3 jenis garis yaitu: a) bold and solid arc (default transition), garis yang menghubungkan tahap pertama ketahap kedua dan seterusnya, disebut "tahap yang seharusnya" dilalui oleh pencari informasi. b) dash arc (high probablity transition), garis putus-putus merupakan langkah balik disebut dengan "peluang tinggi" berhubungan dengan tahap yang dituju. dan c) solid arc (low transition probability) garis biasa merupakan langkah balik disebut dengan "peluang rendah" berhubungan dengan tahap yang dituju.

Ada 2 strategi pokok dalam menelusur informasi di lingkungan elektronik yaitu: analytical strategy dan browsing strategy.

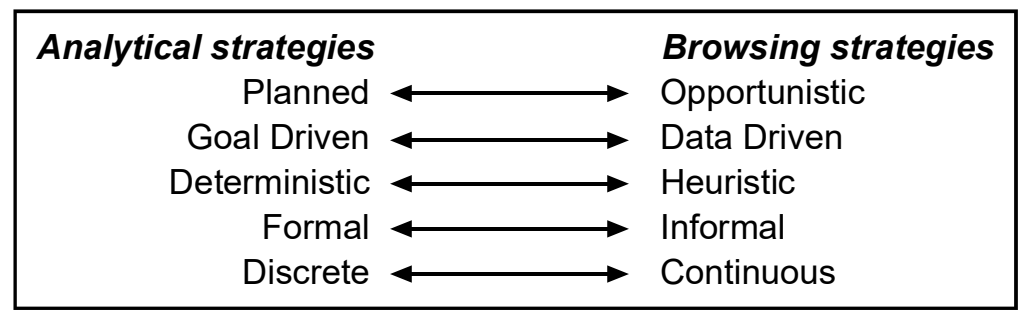

Gambar 2.

Perbedaan pokok antara strategi analitikal dengan browsing 
Pencari informasi yang ahli cenderung memilih strategi analitikal ketika menelusur informasi. Penggunaan index untuk menemukan target seleksi adalah contoh strategi penelusuran analitikal. Sedangkan strategi browsing membutuhkan sedikit beban kognitif dan lebih diminati oleh pencari informasi yang belum berpengalaman.

\section{B. Informasi}

Sejalan dengan perkembangan teknologi informasi maka konsep informasi juga mengalami perubahan-perubahan sesuai situasi dan kondisi yang mempengaruhinya. Definisi-defini tentang informasi bukanlah klasifikasi mutlak tapi merupakan rangkaian perjalanan informasi (information journey) yang kerumitanya semakin bertambah, (Saracevic dan Kantor, 1998).

Buckland (1991), menjabarkan informasi menjadi a) informationas-process (berperan menyampaikan), b) information-as-knowledge (sesuatu yang dirasakan dalam information as-process, pengetahuan yang dikomunikasikan), dan c) information-as-thing, informasi adalah objek seperti data dan dokumen yang dapat memberikan informasi. Pendapat yang berbeda dengan Buckland adalah Barlow dalam (Borgman 2000:58), yang menyatakan bahwa (information obviously not a thing, information is phenomenon with three properties: an activities, a life form, and a relationshi), bahwa informasi bukanlah sebuah objek tapi merupakan sebuah fenomena dengan 3 hal yaitu: kegiatan, bentuk kehidupan, dan hubungan.

Sementara itu Saracevic dan Kantor (1998) mendefinisikan informasi dalam hubungan dengan nilai informasi menjadi 3 rangkaian yang merupakan satu kesatuan. Narrowest sense (pengertian yang paling sempit): informasi adalah tanda atau pesanpesan untuk mengambil keputusan yang melibatkan sedikit atau tidak ada sama sekali proses kognitif. Broader sense (pengertian yang lebih luas), informasi adalah proses kognitif. Informasi tidak dapat diraba melainkan tergantung pada konsep dan pemahaman manusia. Seseorang melakukan proses informasi dan penyatuannya ke dalam struktur kognitif. Broadest sense (pengertian 
yang paling luas): informasi tidak hanya meliputi pesan-pesan, proses kognitif tapi juga hubungan dalam hal situasi, tugas, masalah yang ada, dan lain-lain.

\section{Kebutuhan Informasi}

Kebutuhan adalah konsep psikologis yang dekat hubungannya dengan konsep motivasi, kepercayaan dan nilai-nilai. Kebutuhan adalah taraf awal ketika seseorang merasakan bahwa sebaiknya memanfaatkan kondisi untuk mengetahui sesuatu yang tidak diketahuinya. Pengertian lain tentang kebutuhan adalah taraf awal ketika seseorang merumuskan pernyataan kebutuhan informasi, (Borgman 2000:109).

Kebutuhan informasi bersifat subjektif dan hanya muncul pada pikiran pencari informasi, yang mengarah pada pendekatan problematik. Beberapa hasil penelitian menemukan bahwa kebutuhan informasi dipengaruhi oleh variabel karakteristik seseorang, emosi, demografi, sosial, lingkungan dan ekonomi.

Sementara Chowdhury (1999:181) mengatakan bahwa kebutuhan informasi merupakan suatu konsep yang seringkali samar. Kebutuhan informasi muncul ketika seseorang menyadari pengetahuan yang ada padanya tidak cukup untuk mengatasi permasalahan tentang subjek tertentu.

\section{Pencarian Informasi}

Giannini (1998:363) mengatakan informasi mengandung 3 proses utama yaitu: a) penerimaan informasi (information receiving), pencarian informasi (information seeking), dan penggunaan informasi (information using). Pencarian informasi terjadi bila seseorang mencari informasi khusus untuk memenuhi kebutuhan informasinya. Proses ini dilaksanakan oleh sistem temu kembali informasi di komputer dengan menelusur, menemukan dan menampilkan dokumen. Proses informasi bergerak dari pengguna menuju ke komputer (sistem temu kembali informasi) dan kembali ke pengguna. 
Sementara, Marchionini (1995:5) mengatakan istilah information seeking lebih luas dari information retrieval (temu kembali informasi) karena pencarian informasi lebih berorientasi pada manusia dan lebih terbuka. Pencarian informasi adalah mekanisme yang alami dan diperlukan oleh manusia. Proses ini erat hubungannya dengan pembelajaran dan pemecahan masalah.

Berdasarkan kemahiran dalam pencarian informasi pengguna dapat dibedakan 3 kelompok, Chowdhury (1999:274):a) novice user (pengguna pemula), b) knowledgeable but intermitten user (pengguna berrpengetahuan tentang sistem temu kembali informasi tetapi jarang menggunakannya sehingga menjadi tidak terampil), c) frequent user (pengguna mahir).

\section{E. Internet}

Internet, terutama Web, telah membuat pengaruh yang luar biasa terhadap lingkungan pendidikan dan penelitian, Chowdhury, (1999:400),.

a. mahasiswa, peneliti dan akademisi dapat mengakses katalogkatalog perpustakaan besar dunia, peningkatan jumlah perpustakaan membuat OPAC yang dapat di akses melalui Internet;

b. Sivitas akademika dapat mengakses sejumlah besar database: bibliografi, angka, full-text (termasuk hypermedia), database online;

c. Sivitas akademika dapat melakukan diskusi aktif dengan menggunakan newsgroup untuk bertukar informasi penelitian dan gagasan;

d. dapat mengakses bermacam homepage seperti akademisi, dan institusi penelitian;

e. penelitian kelompok dan kerjasama dapat mempublikasikan di Internet;

f. mahasiswa dan peneliti dengan mudah dapat menemukan informasi akademika, kursus, bea siswa dan lain-lain;

g. Internet juga mempunya potensi melaksanakan pendidikan jarak jauh. 


\section{METODE PENELITIAN}

Penelitian ini menggunakan metode suvei dengan pendekatan analisis kuantitatif. Variabel yang diteliti adalah, a) frekuensi penggunaan Internet, b) pengetahuan cara menelusur, c) pola pencarian informasi.

\section{A. Populasi dan Sampel}

Populasi penelitian ini 2238 mahasiswa berasal dari 12 fakultas dan sekretariat pascasarjana yang khusus mengelola program kajian yang biasa disebut pascasarjana.

Teknik pengambilan sampel berdasarkan besaran sampel dengan menggunakan tabel penarikan sampel (Powell, 1999:80), 331 responden untuk populasi heterogen. Selanjutnya, jumlah ini ditetapkan untuk masing-masing fakultas yang pendistribusian sampel tersebut dilakukan secara proposional. Setelah mendapatkan jumlah sampel per fakultas maka pemilihan responden dilakukan menggunakan sampel aksidental (accidental sampling).

\section{B. Metode Pengumpulan Data}

Alat ukur utama yang digunakan dalam pengumpulan data adalah kuesioner (questionnaire).

\section{Analisa Data}

Data yang terkumpul dikelompokkan menjadi 2 yaitu: a) data responden yang menggunakan Internet, dan b) data responden yang tidak menggunakan Internet. Untuk data yang menggunakan Internet dilakukan pengkodean data. Untuk mengetahui frekuensi variabel yang diamati dalam penelitian ini dilakukan dengan bantuan program aplikasi SPSS (Statistical Package for Social Science). Selanjutnya dilakukan pengkategorian dan tabulasi silang. Pengujian hipotesis menggunakan metode statistik non parametrik Chi-Square (Kai-Kuadrat). 


\section{HASIL DAN PEMBAHASAN}

\section{A. Informasi Umum}

Mahasiswa yang mengakses Internet dalam rangka penyusunan tesis $302(91,24 \%)$, sedangkan $29(8,76 \%)$ mahasiswa tidak. Alasan mahasiswa yang tidak mengakses: a) mahasiswa mengalami kesulitan menelusur, tapi tetap membutuhkan informasi dari Internet dengan bantuan seseorang (intermediary), b) kualitas hasil penelitian di Internet masih diragukan.

Mahasiswa lebih sering mengakses Internet di warnet kampus dan kantor dari pada rumah dan perpustakaan. Mereka belajar mengenai Internet lebih banyak belajar sendiri dengan coba-coba (trial and error) 78 (25,83\%) dan bantuan teman $53(17,55 \%)$. Hanya 6 orang saja yang mengikuti kursus di luar kampus.

Frekuensi penggunaan Internet mahasiswa relatif rendah seperti terlihat pada tabel berikut.

\section{Tabel 1.}

Frekuensi Mahasiswa Menelusur

\begin{tabular}{|l|c|c|}
\hline \multicolumn{1}{|c|}{ Kategori/tingkat penggunaan } & Responden & $\%$ \\
\hline Rendah (1-2 kali/minggu) & 164 & 54,30 \\
Sedang (3-4 kali/minggu) & 82 & 27,15 \\
Tinggi (lebih 5 kali/minggu) & 56 & 18,54 \\
\hline Jumlah & $\mathbf{3 0 2}$ & $\mathbf{1 0 0 , 0 0}$ \\
\hline
\end{tabular}

Kondisi ini bersamaan dengan kenyataan bahwa a) $113(37,41 \%)$ dari 302 mahasiswa mengatakan Internet masih mahal b) ketika menelusur di Internet mahasiswa mendapatkan informasi tidak sebanyak yang dibutuhkan $268(88,7 \%)$.

Dalam mencari informasi mahasiswa cendrung menggunakan 
fasilitas search engine, 81 (26,82\%). Artinya mahasiswa menelusur informasi di Internet relatif aktif dibandingkan dengan hanya mengetik alamat situs. Pada kenyataan 129 (42.71\%) mahasiswa tidak mengetahui situs disiplin ilmu. Mahasiswa yang memanfaatkan kelompok diskusi dan surat elektronik hanya 3.

\section{B. Pengetahuan Mengenai Sistem dan Cara Penelusuran}

Mahasiswa yang tahu 30 (9,93\%) tentang sistem/sarana penelusuran mahasiswa yang memilih 'indeks' dan 'katalog kartu' sebagai sarana penelusuran. Sedangkan mahasiswa memilih kombinasi 'indeks' dan 'katalog kartu' dikategorikan sebagai mahasiswa kurang tahu 149 (49,34\%). Selanjutnya, mahasiswa yang memilih 'buku', 'ensiklopedia' dan 'Internet' atau kombinasi ketiganya dikategorikan sebagai mahasiswa yang tidak tahu 123 $(40,73 \%)$.

Untuk pengetahuan mengenai cara menelusur kategori tahu 224 $(74,17 \%)$ mahasiswa yang memilih 'mengetik istilah/frasa' yang dapat mewakili topik yang dimaksud. Mahasiswa yang memilih 'mengetik istilah dengan menggunakan AND' atau 'kombinasi' dikategorikan sebagai mahasiswa kurang tahu 62 (20,53\%). Selanjutnya, mahasiswa yang memilih 'mengetik seluruh topik' dikategorikan sebagai tidak tahu 16 (5,30\%). .

Untuk mengetahui apakah ada hubungan antara frekuensi menelusur dengan pengetahuan mengenai cara menelusur mahasiswa dilakukan pengujian menggunakan Chi-Square. Pengujian tersebut dilakukan dengan membuat tabulasi silang mengenai profil mahasiswa berdasarkan kategori frekuensi menelusur dan kategori pengetahuan mengenai cara menelusur, seperti yang tercantum pada tabel berikut. 


\section{Tabel 2.}

Profil Mahasiswa Berdasarkan Kategori Frekuensi Menelusur dengan Pengetahuan Mengenai Cara Menelusur

\begin{tabular}{|l|r|r|r|r|}
\hline \multicolumn{5}{|c|}{ Frekuensi Menelusur } \\
Pengetahuan \\
Cara Menelusur & Tinggi & Sedang & Rendah Jumlah \\
\hline & & & & \\
\cline { 2 - 5 } Tahu & 39 & 55 & 130 & 224 \\
Kurang & 14 & 24 & 24 & 62 \\
Tidak tahu & 3 & 3 & 10 & 16 \\
\hline \multicolumn{1}{|c|}{ Jumlah } & $\mathbf{5 6}$ & $\mathbf{8 2}$ & $\mathbf{1 6 4}$ & $\mathbf{3 0 2}$ \\
& & & & \\
\hline
\end{tabular}

$X^{2}$ hasil perhitungan adalah 8,2782 . Selanjutnya nilai tersebut dibandingkan dengan nilai $X^{2}$ dari tabel dengan derajat bebas 4 dan taraf signifikansi (a) sebesar 0,05, yaitu sebesar 9,4877. Karena $X^{2}$ hasil perhitungan lebih kecil dari $\mathrm{X}^{2}$ tabel maka $\mathrm{H}_{0}$ diterima. Hal ini menunjukkan bahwa tidak ada hubungan yang signifikan antara frekuensi menelusur dengan pengetahuan mengenai cara menelusur mahasiswa.

\section{Pola Pencarian Informasi}

Mahasiswa yang 'mengetahui secara spesifik kebutuhan informasi' dan 'menyadari bahwa mereka harus melakukan pencarian informasi' $264(87,4 \%)$ dari 302. Untuk tahap-tahap yang seharusnya (mendefinisikan masalah, memilih sistem penelusuran, merumuskan pertanyaan, melaksanakan penelusuran, memeriksa hasil penelusuran, memilah hasil penelusuran, dan mengakhiri penelusuran) hasil penelitian mengungkapkan bahwa mahasiswa melakukan tahap-tahap yang seharusnya terpisah-pisah diantara tahap-tahap pencarian informasi. Ada mahasiswa yang tidak diketahui kapan melakukan tahap-tahap yang seharusnya. 
Bahkan ada mahasiswa yang melakukannya berulang-ulang, seperti tabel berikut.

\section{Tabel 3.}

Tahap Mendefinisikan Masalah

\begin{tabular}{|l|c|c|}
\hline Saat Dilakukan Pendefinisian Masalah & Frekuensi & $\%$ \\
\hline $\begin{array}{l}\text { 1. setelah mengenali dan menerima } \\
\text { masalah }\end{array}$ & 89 & 29,47 \\
2. setelah memilih sistem penelusuran & 59 & 19,54 \\
3. setelah merumuskan pertanyaan & 50 & 16,56 \\
\hline \multicolumn{1}{|c|}{ Jumlah } & $\mathbf{1 9 8}$ & $\mathbf{6 5 , 5 7}$ \\
\hline Tabel 3 menunjukkan bahwa tahap 'pendefinisian masalah'
\end{tabular}

dilakukan bervariasi. $53(17,55 \%)$ mahasiswa yang tidak 'mendefinisikan masalah' tapi langsung 'menelusur' 28 (9,3\%), 'merumuskan pertanyaan' 12 (4\%), 'memilih sistem penelusuran' 9 (3\%), dan 'mengenali dan menerima masalah' 4 (1,3\%). Ada 51 $(16,88 \%)$ mahasiswa tidak diketahui kapan 'mendefinisikan masalah'.

Gambaran awal pencarian informasi mahasiswa yang telah 'mengenali dan menerima masalah' ada 4, a) ke tahap 2, 89 $(33,71 \%)$, b) ke tahap 3, 68 (25,76\%), c) ke tahap 4, $54(20.45 \%)$, d) ke tahap 5, $53(20,08 \%)$.

302 mahasiswa yang melakukan pencarian informasi di Internet dalam rangka penyusunan tesis ternyata tidak satupun pola pencarian mahasiswa yang sesuai dengan model Marchionini untuk tahap yang seharusnya. Namun begitu, ada 13 mahasiswa yang mendekati model Marchionini seperti terlihat pada tabel berikut: 


\section{Tabel 4.}

Pencarian Informasi Mahasiswa yang mendekati Model Pencarian Informasi Marchionini

\begin{tabular}{|ll|c|r|}
\hline \multicolumn{2}{|c|}{ Tahap Penelusuran } & Frekuensi & $\%$ \\
\hline 1. & $1-2-3-4-5$ & 3 & 23,08 \\
2. & $1-2-4-5-5-6-7-8$ & 1 & 7,69 \\
3. & $1-2-3-5-5-7-7-8$ & 2 & 15,38 \\
4. & $1-2-5-5-5-6-7-8$ & 2 & 15,38 \\
5. & $1-4-4-4-5-6-7-8$ & 1 & 7,69 \\
6. & $1-3-3-2-5-6-7-8$ & 1 & 7,69 \\
7. & $1-2-3-5-5-6-7-8$ & 1 & 7,69 \\
8. & $1-2-3-4-6-6-7-8$ & 1 & 7,69 \\
9. & $1-2-4-4-5-6-7-8$ & 13 & 100 \\
\hline \multicolumn{2}{|c|}{ Jumlah } & & \\
\hline
\end{tabular}

\section{Pembahasan}

268 mahasiswa hanya mendapatkan beberapa informasi tidak sebanyak yang dibutuhkan. Hal yang sama pernah ditemukan Kaminer (1997) pencari informasi harus mempunyai keterampilan menelusur. Kondisi ini kemungkinan disebabkan frekuensi mahasiswa menelusur rendah. Rendahnya frekuensi menelusur bisa juga karena a) Internet masih mahal dan b) strategi penelusuran mahasiswa yang tidak efektif sehingga mahasiswa browsing kemana-mana. Disamping itu dapat pula dihubungkan dengan cara belajar mahasiswa tentang Internet, sendiri dengan coba-coba dan bantuan teman. Meskipun cara belajar seperti ini adalah belajar orang dewasa namun sering kurang terstruktur dibandingkan dengan membaca buku panduan atau kursus.

Hasil yang diperoleh mahasiswa baik yang frekuensi 'tinggi', 'sedang' dan 'rendah' tidak membuktikan bahwa frekuensi 'tinggi' mendapatkan hasil sebanyak yang dibutuhkan atau lebih dari yang 
dibutuhkan. 18 dari 302 mahasiswa memperoleh hasil sebanyak yang dibutuhkan. 9 dari 18 mahasiswa tersebut masuk kelompok frekuensi 'rendah' dan hanya 2 mahasiswa kelompok frekuensi 'tinggi'. 12 dari 302 mahasiswa memperoleh hasil lebih dari yang dibutuhkan. Masing-masing 5 dari 12 mahasiswa masuk kelompok frekuensi 'rendah' dan 'tinggi'. Hal ini terjadi kemungkinan disebabkan mahasiswa sangat menyadari keterbatasan pengetahuan dan keterampilan menelusur yang dimiliki. Sehingga mahasiswa tidak mempunyai harapan yang tinggi untuk mendapatkan hasil yang relevan. Penemuan ini sesuai dengan Zhang (2001) mengatakan pencari informasi perlu memahami sistem ketika berinteraksi dengan Internet sehingga pencari informasi dapat menemukan informasi yang cocok secara efektif dan efisien dan dapat memberikan kepuasan bagi pengguna. Disamping itu temuan ini sejalan dengan hasil penelitian yang dilakukan Bruce (1998) bahwa tidak ada perbedaan penting tingkat kepuasan dalam pencarian informasi di Internet baik yang menelusur setiap hari, mingguan, bulanan atau 6 bulanan.

Ada 2 jenis pencari informasi, yaitu, a) pencari informasi aktif, lebih banyak merumuskan pertanyaan (query) dengan menggunakan fasilitas search engine ketika menelusur, b) pencari informasi pasif, langsung mengetik alamat situs. Marchionini (1995) menegaskan bahwa pencari informasi yang aktif adalah pencari informasi yang menggunakan strategi analitikal. Temuan di lapangan menunjukkan meskipun mahasiswa lebih sering menggunakan fasilitas search engine tapi penelusuran yang dilakukannya cenderung menggunakan strategi browsing. Mahasiswa menggunakan fasilitas search engine bukan karena termasuk pencari informasi aktif tapi disebabkan karena mahasiswa kurang mengetahui situs disiplin ilmu $129(42,71 \%)$.

Kurangnya mahasiswa menggunakan operator Boolean 9 (2,98\%) juga pernah ditemukan dalam penelitian Silverstein et.al dalam Lucas dan Topi (2002). Menurut Marchionini (1995) salah satu cara untuk merumuskan query yang tepat dengan menggunakan operator Boolean. Mahasiswa dalam penelitian ini cendrung pencari 
informasi aktif, tidak menggunakan strategi analitikal tapi menggunakan strategi browsing yang bersifat keberuntungan, cenderung bolak balik berorientasi pada data, tidak formal dan berkelanjutan. Hal ini terjadi kemungkinan ketidaktahuan mahasiswa bagaimana membangun sebuah query untuk penelusuran yang efektif. Bisa juga disebabkan keterbatasan pengetahuan mahasiswa dalam merumuskan pertanyaan dan rendahnya frekuensi penelusuran.

Bila dihubungkan dengan pendapat Chowdury (1999) mengenai kemahiran dalam pencarian informasi di lingkungan elektronik maka mahasiswa ini dikelompokkan pengguna pemula (novice user). Temuan ini juga mengungkapkan bahwa hanya 30 dari 302 mahasiwa yang mengetahui bahwa indeks dan katalog kartu disebut sebagai sarana penelusuran. Hal ini terjadi kemungkinan disebabkan kurangnya pengetahuan mahasiswa tentang ilmu kepustakaan.

Tahap 'penelusuran' telah mulai dilakukan setelah tahap 'mengenali dan menerima masalah informasi'. Hal ini terjadi kemungkinanan a) bagi pencari informasi utama dan teruma adalah menelusur b) kemudahan yang dibayangkan pencari informasi ketika menelusur dengan hanya satu kata kunci pencari informasi akan mendapatkan beratus bahkan beribu informasi.

Penelitian ini mengungkapkan frekuensi mahasiswa memeriksa hasil penelusuran rendah. Kemungkinan disebabkan mahasiswa memeriksa hasil penelusuran pada saat online sehingga menyebabkan waktu dan biaya akan bertambah. Bahkan, 80 mahasiswa memeriksa hasil penelusuran dengan membaca seluruh hasil. Kondisi ini bisa juga disebabkan mahasiswa merasa tidak perlu memeriksa hasil penelusuran tapi lebih mengutamakan pemilahan hasil penelusuran.

Bila pencari informasi merasa hasil yang diperoleh setelah menelusur cukup bisa melanjutkan ke tahap 'pemilahan informasi'. Mahasiswa yang langsung 'memilah hasil penelusuran' setelah 
'memeriksa hasil penelusuran' 189 mahasiswa. Ternyata tahap 'pemilahan' telah mulai dilakukan setelah melaksanakan 'penelusuran' sehingga frekuensi tahap ini tinggi. Berbeda dengan tahap pemeriksanaan hasil sebelumnya. Hal ini kemungkinan disebabkan ketika mahasiswa melakukan pemeriksaan membutuhkan beban kognitif dan waktu yang lama sehingga mempengaruhi waktu penelusuran mahasiswa.

Bila hasil yang diharapkan terpenuhi maka pencarian informasi dapat berakhir bila tidak pencarian akan belanjut. 132 mahasiswa langsung mengakhiri penelusuran setelah memilah meskipun hasil yang diperoleh belum terpenuhi. Penelusuran informasi untuk lingkungan elektronik jarang sempurna hanya dengan sebuah pertanyaan tunggal. Sering temuan awal menjadi umpan balik perumusan pertanyaan dan pelaksanaan penelusuran selanjutnya.

Hasil penelitian mengungkapkan bahwa pola pencarian informasi mahasiswa cenderung berulang-ulang. Hal ini terjadi karena penelusuran itu bukan dogmatis yang telah ditetapkan berdasarkan aturan tapi merupakan pragmatis yang dilandasi dengan kebutuhan masing-masing pencari informasi.

\section{KESIMPULAN DAN SARAN}

\section{A. Kesimpulan}

a. Frekuensi mahasiswa menelusur di Internet dikelompokkan dalam kategori rendah. Kondisi ini bersamaan dengan kenyataan $268(88,74)$ mahasiswa mendapatkan informasi tidak sebanyak dibutuhkan, 18 (5,96\%) mahasiswa mendapatkan informasi sebanyak dibutuhkan, 12 (3,97\%) mahasiswa lebih dari dibutuhkan, $4(1,32 \%)$ mahasiswa tidak mendapatkan. Penyebabnya 113 mahasiswa mengatakan Internet masih mahal.

b. Tidak terdapat hubungan yang signifikan antara frekuensi menelusur dengan pengetahuan mengenai cara menelusur mahasiswa $\left(\mathrm{H}_{0}\right.$ diterima). $\mathrm{X}^{2}$ dari tabel dengan derajat bebas 4 dan taraf signifikansi (a) sebesar 0,05 , yaitu sebesar 9,4877 ( 
$\mathrm{X}^{2}$ hasil perhitungan lebih kecil dari $\mathrm{X}^{2}$ tabel).

c. Pola pencarian informasi mahasiswa di Internet sangat bervariasi. Temuan menunjukkan bahwa tidak ada satupun pola pencarian informasi mahasiswa yang sesuai dengan model pencarian informasi Marchionini.

$264(87,42 \%)$ mahasiswa ke tahap pertama, $89(29,47 \%)$ mahasiswa ke tahap kedua, $86(28,48 \%)$ mahasiswa ke tahap ketiga, $46((15,23 \%)$ mahasiswa ke tahap keempat, $93(30,79 \%)$ mahasiswa ke tahap kelima, $88(29,14 \%)$ mahasiswa ketahap keenam, $189(62,58 \%)$ mahasiswa ketahap ketujuh, $132(43,71 \%)$ mahasiswa ketahap kedelapan.

\section{B. Saran}

a. Hasil penelitian ini menunjukkan bahwa pengetahuan mahasiswa baik mengenai sistem atau sarana penelusuran maupun mengenai cara menelusur adalah rendah. Akibatnya mahasiswa memperoleh hasil tidak sebanyak yang dibutuhkan. Kondisi ini agar menjadi perhatian pihak lembaga, staf pengajar dan akademik untuk membekali mahasiswa dengan pengetahuan dan teknik menelusur di media elektronik.

b. Pengguna jasa layanan Internet memperlihatkan peningkatan di lingkungan kampus. Data ini diindikasikan dengan banyak bermunculan pusat layanan Internet baik yang diselenggarakan oleh Mweb atau provider lain maupun perpustakaan jurusan, fakultas dan UPT. Berdasarkan data penelitian ini pengetahuan dan keterampilan menelusur mahasiswa masih belum maksimal untuk itu pusat layanan Internet dapat mensosialisasikan model pencarian informasi Marchionini untuk pengguna pemula.

c. Pembahasan penelitian ini belum dapat menjawab dengan tuntas dan pasti yang menjadi penyebabnya, bahkan seringkali dalam pembahasan dimulai dengan kata "kemungkinan" oleh karena itu dalam penelitian selanjutnya disamping kuesioner peneliti dapat juga melakukan wawancara.

d. Keterbatasan waktu, tenaga dan biaya, maka penelitian ini hanya 
terbatas pada ruang lingkup tahap yang seharusnya dari Model Marchionini. Untuk itu disarankan penelitia selanjutnya dapat melakukan penelitian yang lebih dalam terhadap peluang tinggi dan peluang rendah dengan menggunakan pendekatan kualitatif.

\section{DAFTAR PUSTAKA}

Borgman, Christine L. (2000). From Gutenberg to the Global Information Infrastructure: Access to Information in the Networked World. The MIT Press, United States of America.

Bruce, Harry. (1998). "User Satisfaction with Information Seeking on the Internet", Journal of the American Society for Information Science, 49(6):541-556

Buckland, Michael. (1991) "Information as a thing", Journal of the American Society for Information Science, 42(5):351-360.

Chowdhury, G.G. (1999). Introduction to Modern Information Retrieval. London:

Library Association Publishing.

Giannini, Tula. (1998). "Information Receiving: A Primary Model of the Information Process", Contributed Papers-User Information Interaction, ASIS, p.362-371.

Kaminer, Noam. (1997). "Scholars and the use of the internet", Library and Information Science Research, 19(4):239-345.

Khomsan, Ali. (2002). Strategi Percepatan Pendidikan Pascasarjana, Republika, Rabu 13 Februari 2003, hal. 4, Jakarta.

Lucas, Wendy dan Topi, Heikki. (2002) "Form and Function: The Impact of Query Term and Operator Usage on Web Search Results", Journal of the American Society for Information Science, 53(2):95-108.

Marchionini, Gary. (1995). Information Seeking in Electronic Environment, Cambridge University Press, United States of America.

Powell, Ronald R. (1999). Basic Research Methods for Librarians, Third Edition. Alex Publishing Corporation Greenwich, Connecticut. London. England.

Saracevic, Tefko and Kantor Paul B. (1998). "Studying the Value of Library and Information Services in Corporate Environments", Contributed PapersEvaluating Services, ASIS: p. 411-420.

Zhang, Yin. (2001) "Scholarly Use of Internet-based Electronic Resources", Journal of the American Society for Information Science, 52(8):628-654. 